\title{
The Effects of Prolotherapy in Recreational Athletes with Plantar Fasciitis
}

\section{Plantar Fasiitli Rekreasyonel Sporcularda Proloterapi Uygulamasının Etkinliği}

\author{
Ali Haydar Apaydın¹, Aydan Örsçelik², Yavuz Yıldız \\ ${ }^{1}$ Academy of Gendarmerie and Coastal Security, Department of Sports Medicine, Ankara, Turkey \\ ${ }^{2}$ University of Health Sciences, Gülhane Education and Resaearch Hospital, Department of Sports Medicine, Ankara, \\ Turkey
}

\section{A. H. Apaydın 0000-0002-7538-3881 \\ A. Örsçelik \\ 0000-0002-8610-8869 \\ Y. Yildiz \\ 0000-0001-7050-9628}

Geliş Tarihi / Date Received: 10.10.2017

Kabul Tarihi / Date Accepted: 10.12.2017

Yayin Tarihi / Date Published: 02.03.2018

\section{Yazışma Adresi /} Corresponding Author:

Ali Haydar Apaydın Jandarma ve Sahil Güvenlik Akademisi, Spor Hekimliği, Ankara, Turkey.

E-mail:dr.alihaydar@gmail.com

C02018 Türkiye Spor Hekimleri Derneği. Tüm hakları saklıdır.

\begin{abstract}
Objectives: In this study; it was tried to examine the efficacy of the prolotherapy method in the treatment of recreational athletes who have plantar fasciitis and to determine its place in the treatment.

Material and Methods: Of the patients who were admitted to the polyclinic with heel pain, the ones diagnosed with unilateral plantar fasciitis were determined. Thirty recreational athletes who were aged 25 to 50 , had pain for at least six months, and who have not been healed by conservative treatment were included in the study. Patients were evaluated by visual pain scale, foot and ankle outcome score and balance coordination test. These evaluations were made before the treatment and three months following the first application. The extremities that patients did not complaint about were used as the control side. A 15\% dextrose solution was preferred as proliferating agent for prolotherapy. In total, injections were made at seven points (to the beginning and end of plantar fascias). The same procedure was repeated two weeks later.

Results: When pre- and post-treatment values were compared; a statistically significant difference was found between the scores of visual pain scale, foot and ankle outcome score and balance coordination test $(p<0.01)$.

Conclusion: According to the results of the research, one can conclude that the application of prolotherapy provides symptomatic and functional improvement in recreational athletes with plantar fasciitis. Prolotherapy application seems to be an alternative treatment method in patients who have not been healed by conservative treatment.
\end{abstract}

Key Words: Prolotherapy, plantar faciitis, recreational athletes, heel pain

\section{ÖZ}

Amaç: Bu çalışmada; proloterapi yönteminin, plantar fasiitli rekreasyonel sporcuların tedavisindeki etkinliğinin incelenmesi ve tedavideki yerinin belirlenmesine çalışıldı.

Gereç ve Yöntemler: Polikliniğe topuk ağrısı ile başvuran hastalardan tek taraflı plantar fasiit tanısı konulanlar belirlendi. Çalışmaya 25-50 yaş aralığında, en az altı aydır yakınması bulunan, konservatif tedaviden fayda görmeyen 30 rekreasyonel sporcu dahil edildi. Hastalar görsel ağı ölçeği, ayak-ayak bileği araştırması ve denge koordinasyon testi ile değerlendirildi. Bu değerlendirmeler tedavi öncesi ve ilk uygulamadan üç ay sonra yapıldı. Hastaların yakınma belirtmedikleri ekstremiteleri kontrol olarak kullanıldı. Proloterapi uygulaması için proliferan madde olarak \%15'lik dekstroz çözeltisi tercih 
edildi. Toplamda yedi noktaya (plantar fasya başlangıcına ve sonlanma noktalarına) enjeksiyon uygulandı. Aynı uygulama iki hafta sonra tekrarlandı.

Bulgular: Tedavi öncesi ve tedavi sonrası değerler karşılaştırıldığında; görsel ağrı ölçeği, ayak-ayak bileği araştırması ve denge koordinasyon testi değerleri arasında istatistiksel olarak anlamlı fark saptandı $(p<0.01)$.

Sonuç: Ulaşılan sonuçlar ışığında, proloterapi uygulamasının plantar fasiitli rekreasyonel sporcularda semptomatik ve fonksiyonel iyileşme sağladığı ifade edilebilir. Proloterapi uygulaması konservatif tedaviden fayda görmeyen olgularda alternatif bir yöntem olarak görünmektedir.

Anahtar Sözcükler: plantar fasiit, proloterapi, rekreasyonel sporcular, topuk ağrısı

Available at: http://journalofsportsmedicine.org and http://dx.doi.org/10.5152/tjsm.2018.088

Cite this article as: Apaydın $\mathrm{AH}$, Orscelik A, Yildiz Y. The effects of prolotherapy in recreational athletes with plantar fasciitis Turk J Sports Med. 2018;53:37-46.

\section{GíRiş}

Plantar fasiit (PF) erişkinlerde topuk ağrısının en sık nedeni olarak bilinir (1). Topuk ağrısı olanların yaklaşık olarak \%80'inde PF bulunmaktadır. Ayrıca her on kişiden birinin hayatlarının bir döneminde topuk ağrısı yaşamış olduğu ifade edilmektedir (2).

Görülme sıklığı 40-60 yaş arasında daha fazla olmakla birlikte, koşucularda daha küçük yaşlarda da görülebilir. PF etiyolojisinde en çok sıralanan nedenler arasında Vücut Kütle İndeksi (VKI) yüksekliği, uzun süreli ayakta durma, pes planus ve ayak bileği dorsifleksiyon açısında azalma gibi biyomekanik ayak problemleri yer alır.

PF oluşumunda mekanik yüklenme ve aşırı kullanım sonucu oluşan mikroskobik yırtıklar ve bunu izleyen yetersiz onarım süreci ana neden olarak görülmektedir. Bir başka ifadeyle; tekrarlayan mikrotravmaların normal iyileşme sürecini sekteye uğrattığı ve bu durumun plantar fasyada kronik enflamasyona neden olduğu ifade edilmektedir (3). PF'nin cerrahi tedavisi sonrasinda yapilan incelemelerde plantar fasyada kollajen dejenerasyonu, fibrillerde düzensizlik, mukoid dejenerasyon, fibrovasküler hiperplazi ve kalsifikasyon sıklıkla rapor edilirken; polimorfonükleer lökosit, lenfosit ve makrofaj gibi aktif enflamatuvar hücreler nadiren bildirilmiştir. PF için aktif enflamatuvar bir durumu yansıtan tendinit veya entezit yerine daha çok dejeneratif bir tanımlama olan tendinozis terimi tercih edilmektedir $(2,3)$. Özetle; PF'nin temelinde çeşitli nedenlerle ortaya çıkan bir kronik enflamasyon söz konusudur.
PF tanısı öykü, risk faktörlerinin değerlendirilmesi ve fizik muayene bulgulariyla rahatlıkla konulabilir (4). Ağrı genellikle inferior medial kalkaneal çıkıntıya lokalizedir. Bu ağrı sabahları ve uzun süreli istirahat sonrası en fazla olup, birkaç dakikalık yürüyüș sonrası azalır ancak günün sonunda aktiviteye devam edildiğinde tekrar artar (5).

Hastaların büyük bölümü konservatif yöntemlerle tedavi edilirler (6). PF olgularının \%90'a yakını konservatif tedaviyle iyileşir (7). Konservatif tedaviye yanit vermeyen olgularda ise lokal enjeksiyonlar, vücut dışı şok dalga tedavisi (ESWT) ve cerrahi yöntemler kullanılmaktadır (4). PF tedavisinde lokal steroid enjeksiyonları rüptür riskini arttırdığından, cerrahi yöntemler ise olası komplikasyonlar nedeniyle daha az tercih edilmektedir $(8,9)$. PF tedavisinde ESWT uygulamak için ise cihaz gereksinimi bulunmaktadır.

Proloterapi; yetersiz iyileşmiş yapıların tedavisi için kullanılan bir yöntem olarak tanımlanır $(10,11)$. Proloterapi; ligament ve tendonlara yüksek yoğunluklu dekstroz gibi proliferan maddelerin enjeksiyonuna dayanan, yenileyici enjeksiyon tedavisi olarak bilinmektedir (12). İrritan, osmotik ve kemotaktik başlıkları altında birçok proliferan madde tanımlanmıștır (13). Kemotaktik ajanlar hariç tüm proliferan çözeltilerin ortak etkisi lokal irritasyon oluşturarak enflamasyon başlatmaktır. Enflamasyon; fibroblast proliferasyonu ve sonrasinda kollajen doku olușumuyla sonuçlanan yara iyileșme döngüsünün ilk aşamasıdır (10). Bu noktadan hareketle temelinde dejenerasyon olan ve süreğen bir hal almış lateral epikondilit, aşil tendinopatisi ve plantar fasiit gibi problemlerin tedavisinde kullanılmaya başlanmıştır (14). 
$\mathrm{Bu}$ çalışmada; proloterapi yönteminin, plantar fasiit tedavisindeki etkinliği incelenmeye çalışıldı.

\section{GEREÇ ve YÖNTEM}

Prospektif olarak planlanan bu çalışmaya Keçiören Eğitim ve Araștırma Hastanesi Etik Kurulunun B.10.4.İSM.4.06.68.49/608 sayı ve
27.08.2014 tarihli izni ile başlandı. Bu kapsamda çalışmaya; Eylül 2014 ile Mart 2015 tarihleri arasında polikliniğine topuk ağrısı ile başvuran hastalardan çalışmaya dahil olma şartlarını (Tablo 1) sağlayan ve klinik olarak PF tanısı doğrulanan 30 hasta dahil edildi.

Tablo 1. Çalış̧ma koşulları

\section{Çalışmaya Dahil Olma Kıstasları}

1. 25- 50 yaş arasında olanlar.

2. En az 6 aydır yakınması bulunanlar.

3. Klinik veya radyolojik olarak tek taraflı Plantar Fasiit tanısı konulanlar.

4. Plantar fasiit tedavisi için cerrahi tedavi veya kortikosteroid enjeksiyonu yapılmamış olanlar.

\section{Çalışma Dışı Kalma Kıstasları}

1. Klinik veya radyolojik olarak Plantar Fasiit dışında tanı alanlar.

2. Ayak veya ayak bileğinde ağrıya ve fonksiyon kaybına neden olabilecek, daha önce tanı konulmuş hastalığı olanlar (eklemin diğer patolojileri, vb).

3. Diyabet, hipertansiyon, hiperlipidemi, periferik arter hastalığı, ankilozan spondilit ve romatoid artirit v.b kronik hastalığı bulunanlar.

4. Gebelik bulunan veya emziren kadınlar.

5. Tedavi sonrası kontrollere gelmeyen hastalar.

Polikliniğe topuk ağrısı ile başvuran hastalardan öykü, fizik muayene ve radyolojik değerlendirme sonucunda deneyimli Spor Hekimliği uzmanı tarafından tek taraflı PF tanısı konulanlar belirlendi. Hastalara proloterapi uygulaması hakkında ayrıntılı bilgi verildi. Değerlendirme için görsel ağrı ölçeği (VAS), ayak ayak bileği araştırması (FAOS) ve denge koordinasyon testi sonuçlarına bakıldı. Hastaların yakınma belirtmedikleri ekstremiteleri için de denge koordinasyon testi uygulandı. Bu değerlendirmeler tüm hastalar için tedavi öncesi ve ilk uygulamadan üç ay sonra yapıldı.

\section{Prosedürler}

Proloterapi uygulaması için \%15'lik dekstroz + $\% 0.02$ 'lik lidokain çözeltisi hazırlandı. Uygulama öncesi hastanın en fazla ağrı duyduğu nokta olan plantar fasya başlangıcı/medial kalkaneal çıkıntı işaretlendi. Enjeksiyon yapılacak bölge antiseptik povidin iyot çözeltisi ile temizlendi. Toplamda yedi noktaya; plantar fasya başlangıcına medialden ve lateralden 1'er ml, plantar fasya sonlanma noktalarına 0.5 'er ml olmak üzere $4.5 \mathrm{ml} \% 15^{\prime}$ lik dekstroz $+\% 0.02$ 'lik lidokain enjeksiyonu yapıldı. Aynı uygulama iki hafta sonra tekrarlandı.

Tüm hastalara altı haftalık egzersiz programı verildi. Egzersiz programi; gastrokinemius ve soleus kasları ile plantar fasya için germe egzersizlerini içermekteydi. Egzersizler deneyimli bir fizyoterapist tarafından 15 tekrar, 10 s süreli ve günde iki kez yapılacak şekilde tanımlandı. 


\section{Değerlendirme ölçütleri}

Çalışmaya katılan hastalar; sabah ağrısını belirlemek için görsel ağrı ölçeği (VAS), belirti ve bulguların günlük yaşama, iş hayatına, spor ve eğlence aktiviteleri ile yaşam kalitesine etkisini değerlendirmek için ise ayak-ayak bileği araştırması (FAOS) ile değerlendirildi. Fonksiyonel durumun test edilmesinde denge ve koordinasyon testi yapıldı. Kullanılan değerlendirme ölçütleri başlangıçta ve ilk tedaviden üç ay sonra uygulandı.

Görsel ağrı ölçeği (VAS): VAS ile sabah ilk birkaç adım sırasında yaşanan ağrı değerlendirildi. Ağrı şiddetini belirlemek için $10 \mathrm{~cm}$ 'lik bölmesiz bir doğru kullanıldı. Sifir değerinin ağrı yokluğunu, 10 değerinin ise ağrının dayanılmazlığını gösterdiği anlatıldı. Hastaya sabah ilk birkaç adım sırasında yaşanılan en şiddetli ağrıya uyacak noktayı doğru üzerinde işaretlemesi söylendi. Ölçülen değer hasta takip formunda kayıt altına alındı.

Denge ve koordinasyon testi: Denge durumunu ölçmede bilgisayarlı denge cihazı (Biodex Balance System SD) kullanıldı. Biodex denge ölçüm cihazında tüm yönlere eş zamanlı harekete izin veren dairesel bir platform bulunmaktadır. $\mathrm{Bu}$ platformun stabilizasyonu 1'den 12'ye kadar numaralandırmış rakamlarla ayarlanmaktadır ve 1 değeri platformun en hareketli olduğu değeri, 12 değeri ise en sabit olduğu değeri ifade etmektedir. Hareketli platform dinamik stres altında dengeyi sağlamak için bireyin kişisel kabiliyetinin ölçümüne yardımcı olmaktadır (15). Platform üzerinde dururken ağırlık merkezinde meydana gelen açısal değişiklikler cihaz tarafından sayısal verilere dönüştürülür (16). Biodex denge cihazında ayrıca görsel geri bildirim sağlayan bir ekran yer almaktadır. Postüral stabilite testinde medial/lateral, anterior/ posterior indeks ve genel (overall) stabilite indeksi (OSI) değerleri elde edilmektedir.

$\mathrm{Bu}$ çalışmada bütün hastalara tedavi öncesi ve sonrası postüral stabilite testi uygulandı. Test öncesi katılımcılara açıklayıcı bilgi verildi. Deneme testi ve test öncesinde katılımcının denge platformu üstündeki pozisyonu belirlenip kayıt altına alındı, tedavi öncesi ve üçüncü ay sonunda yapılan testler aynı pozisyonda yapıldı. Katılımcıların teste uyumunu sağlamak için sağ, sol ve çift ayak üzerinde beş zorluk seviyesinde 60 s süre ile iki deneme testi yaptırıldı. Deneme testlerinden sonra aynı zorluk derecesinde önce sağlam taraf, sonra hasta taraf teste alındı. 60 saniyelik testin sonunda her iki tarafın "overall" stabilite indeksi (OSI) değerleri kaydedildi.

Ayak-ayak bileği araştırması (FAOS): Ayakayak bileği araştırması (Foot \& Ankle Outcome Score-FAOS); 2001 yılında Roos ve arkadaşları tarafından geliştirilmiştir ve ayak-ayak bileği problemlerinde yaygın olarak kullanılmaktadır (17). Karatepe ve ark. tarafindan 2009 yılında yapılan iç güvenilirlik çalışmasında beş bölüm için Cronbach alfa katsayısı 0.79-0.97 arasında, test-tekrar test korrelasyon katsayısı ise 0.70 0.96 aralığında bulunmuştur. FAOS Türkçe çevirisinin geçerliliği ve güvenilirliği gösterilmiş ve Türk toplumunda ayak-ayak bileği problemi olanlarda kullanılabileceği belirtilmiştir (18).

FAOS sorgulama formunun doldurulması sırasında hastalara eşlik edilmiş, anlayamadıkları sorular açıklanmış ve formun eksiksiz doldurulması sağlanmıştır.

\section{İstatistiksel İncelemeler}

Verilerin analizi SPSS (Statistical Package for Social Science) for Windows v15.0 paket programında yapıldı. Sürekli veriler ortalama \pm standart sapma şeklinde, kesikli veriler ise sayı ve yüzde (\%) olarak gösterildi. Sürekli değişkenlerin grup içi dağılımlarının normal dağılıma uygunluğunun belirlenmesinde KolmogorovSmirnov uyum iyiliği testi kullanıldı. Normal dağılıma uygunluğu saptanan değişkenlerin grup içi karşılaştırmalarında bağımlı gruplarda T-testi, gruplar arası karşılaştırmalarda ise Student Ttesti kullanıldı. Kesikli verilerin karşılaştırılmasında ki-kare testi kullanıldı. Tüm veriler için $\mathrm{p}<0.05$ değeri istatistiksel olarak anlamlı kabul edildi.

\section{BULGULAR}

Çalışmaya PF bulunan 30 hasta dâhil edilmiş, ancak; sekizi ikinci seans tedaviye gelmediği, altısı ise üçüncü ayda yapılan ikinci kontrole 
gelmediği için çalışma dışı kalmışlardır. Bulgular yedisi kadın (\%43.8), dokuzu erkek (\%56.3) olmak üzere 16 hasta üzerinden değerlendirilmiștir.
Katılımcllardan birinin (\%6.3) vücut kütle indeksi $25 \mathrm{~kg} / \mathrm{m}^{2}$ 'nin altında, 10'unun (\%62.5) 25-30 $\mathrm{kg} / \mathrm{m}^{2}$ arasında, beşinin (\%31.3) ise $30 \mathrm{~kg} / \mathrm{m}^{2}$ 'nin üzerindeydi (Şekil 1).

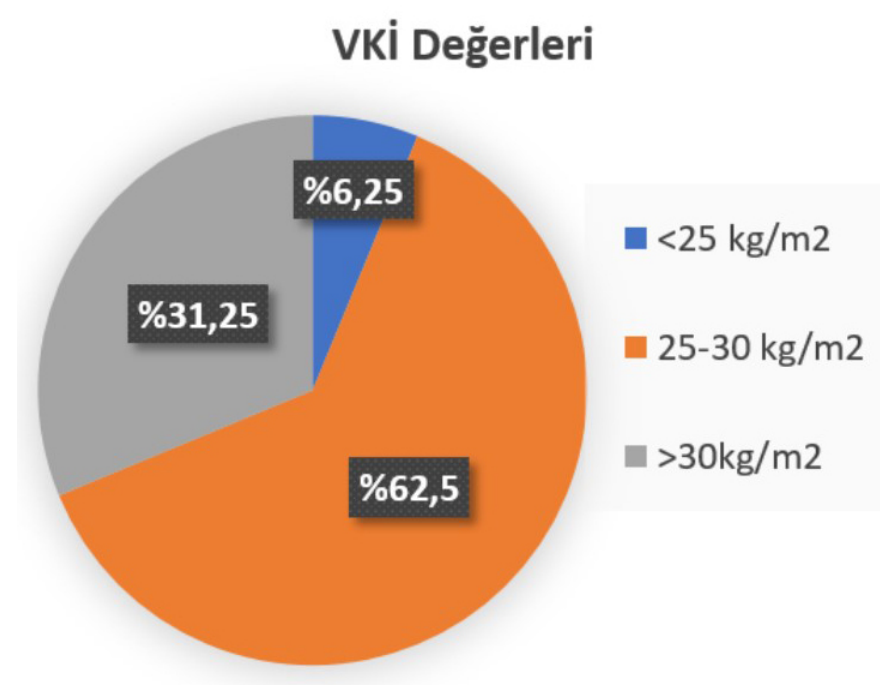

Şekil 1. Hastaların vücut kütle indeksi dağılımı

Tedavi öncesi ve tedavi sonrası VAS, denge ve koordinasyon (OSI) ve FAOS değerleri arasında istatistiksel olarak anlamlı fark saptandı $(\mathrm{p}<0.01)$
(Tablo 2). Tedavi öncesi ve sonrası saptanan ortalama değerler şekil 2,3 ve 4'te gösterilmiștir.

\section{VAS Değerleri}

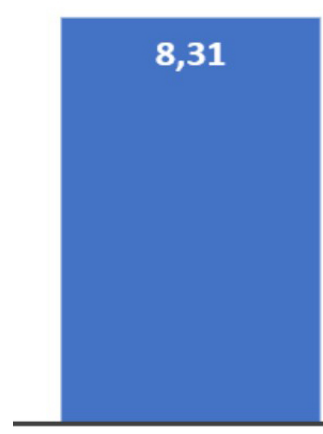

Tedavi Öncesi

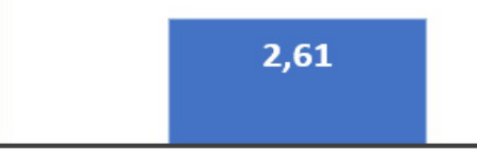

Tedavi Sonrası

Şekil 2. Tedavi öncesi ve sonrası VAS değerleri

\section{Overall Stabilite Indeksi (OSI) Değerleri}

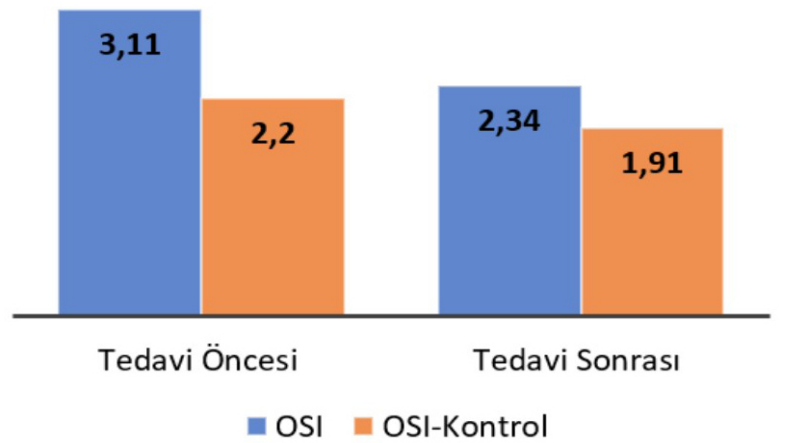

Şekil 3. Tedavi öncesi ve sonrası OSI değerleri 


\section{Ayak-Ayak Bileği Araştırması (FAOS) Değerleri}

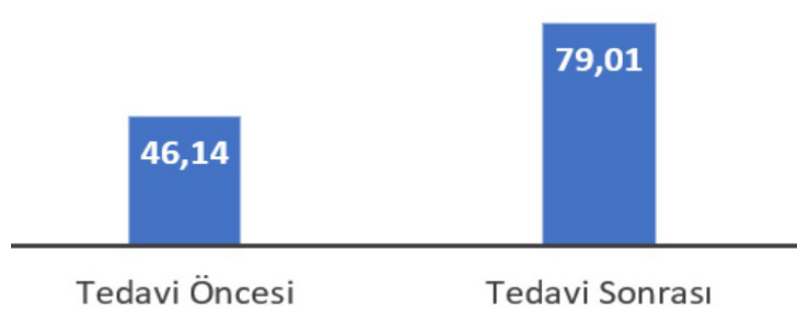

Tedavi öncesinde katılımcıların PF bulunan ekstremiteleri ile kontrol grubu olarak kullanılan ekstremitelerinin denge ve koordinasyon (OSI) değerleri arasında istatistiksel olarak anlamlı fark saptandı. Bu fark tedavi sonrası dönemde azalmakla birlikte, istatistiksel olarak anlamlılığ devam etmekteydi ( $\mathrm{p}<0.05)$, (Tablo 3 ).

Şekil 4. Tedavi öncesi ve sonrası FAOS değerleri

Tablo 2. Proloterapi uygulanan katılımcıların tedavi öncesi ve sonrası grup içi VAS, OSI ve FAOS sonuçlarının karşılaştırılması (Değerler Ort \pm SS olarak)

\begin{tabular}{lccc}
\hline Proloterapi & Tedavi öncesi & Tedavi sonrası & p \\
\hline VAS & $8.31 \pm 0.79$ & $2.61 \pm 0.80$ & $<0.001$ \\
OSI & $3.11 \pm 1.26$ & $2.34 \pm 0.78$ & \\
FAOS & $46.1 \pm 13.5$ & $79.0 \pm 8.77$ & \\
\hline
\end{tabular}

VAS: Görsel ağrı ölçeği; OSI: Overall stabilite indeksi; FAOS: Ayak ayak bileği araştırması

Tablo 3. Proloterapi uygulanan katılımcılar ile kontrol grubunun (sağlam ekstremite) tedavi öncesi ve sonrası OSI sonuçlarının karşılaştırılması

\begin{tabular}{llccc}
\hline & & Proloterapi & Kontrol & p \\
\hline OSI & Tedavi öncesi & $3.11 \pm 1.26$ & $2.20 \pm 1.12$ & $<0.001$ \\
& Tedavi sonrası & $2.34 \pm 0.78$ & $1.91 \pm 0.75$ & \\
\hline
\end{tabular}

OSI: Overall stabilite indeksi

\section{TARTIŞMA ve SONUÇ}

Plantar fasiitli hastalarda proloterapi uygulanması etkinliğinin araştırıldığı bu çalışmada tedavi öncesi ve sonrası tüm değerlendirme ölçütleri arasında anlamlı decede fark saptandı. OSI değerlerinin; sağlam ekstremitelerin sonuçlarına yaklaştı̆̆ı, ancak hasta taraf ile sağlam taraf arasındaki farkın anlamlılı̆̆ını koruduğu belirlendi.

Literatürde PF görülme yaşının 25-64 yaş aralığında olduğu ve 40-60 yaş aralığında bulunma sıklığının arttığı ifade edilmektedir $(2,7,19)$. Çalışmamızda yaş ortalaması $40.4 \pm 6.8$ olarak saptanmış olup hasta grubunun yaş ortalaması literatür ile uyumludur.
Konudaki araștırmalarla kilo fazlalı̆̆ ve PF arasındaki ilişki gösterilmiştir. Riddle ve ark. VKI $30 \mathrm{~kg} / \mathrm{m}^{2}$ ve üzeri olanlarda PF sıklığının arttığını, $25 \mathrm{~kg} / \mathrm{m}^{2}$ altında VKİ'ye sahip olanlarda daha az görüldügünü (20), Rano ve ark. ise 25 $\mathrm{kg} / \mathrm{m}^{2}$ ve üzerindeki VKİ değerlerinin PF için risk olușturduğunu ifade etmișlerdir (21). Hasta grubunun \%62.5'inin VKİ değeri $25-30 \mathrm{~kg} / \mathrm{m}^{2}$ aralığında, \%31.3'ünün VKİ değeri $30 \mathrm{~kg} / \mathrm{m}^{2}$ 'nin üzerindeydi. Hastaların sadece biri (\%6.3) $25 \mathrm{~kg} / \mathrm{m} 2$ 'nin altında bir değere sahipti. Çalışmadaki katılımcıların VKİ değerlerindeki yükseklik literatür verileri ile uyumludur.

PF bulunan hastaların çoğunun bir yıl içerisinde herhangi bir tedavi gerektirmeden iyileșebildiği 
ve konservatif tedaviyle iyileşme oranının \%90'lara ulaşabildiği ifade edilmektedir. Tedavide ilk seçenek konservatif yöntemlerdir. Literatürde; semptomların altı aydan fazla süre bulunması durumunda invazif yöntemlerin kullanılabileceği belirtilmektedir $(1,4,7,22,23)$. Bu çalışmaya en az altı ay süreyle semptomları bulunan, kendi kendine veya konservatif tedaviyle iyileşememiş, daha önce invazif yöntemler uygulanmamış hastalar dâhil edilmiştir. Hastaların semptomatik olduğu süre ortalama $13.4 \pm 8.6$ ay olarak belirlenmiștir.

Proloterapi uygulamasının yapılış şekli, seçilecek çözelti, seans sayı ve sıklığı hakkında görüş birliği sağlanmış değildir. Proliferan madde olarak farklı karışımlar kullanılmakla birlikte, yan etki ihtimali düşük olduğundan yüksek yoğunluklu dekstroz çoğunlukla tercih edilmektedir. Farklı yazarlara göre dekstrozun yoğunluğu \%10-50 arasında, seans aralıkları ise 2-6 hafta arasında değişmektedir $(12,14)$. Ryan ve arkadaşları tarafindan PF bulunan hastalar üzerinde yapılan çalışmada altı hafta arayla \%25'lik dekstroz (24), Kim ve Lee tarafından yapılan çalışmada ise iki hafta arayla yapılan uygulamada $\% 15^{\prime}$ lik dekstroz çözeltisi kullanılmıştır (25).

$\mathrm{Bu}$ çalışmada proloterapi uygulaması iki hafta arayla iki kez yapıldı ve \%15'lik dekstroz çözeltisi kullanıldı. Çalışmamız; kullanılan dekstroz yoğunluğu ve seans sıklığı bakımından Kim ve Lee tarafından yapılan çalışma ile benzerdir.

PF tedavisinde kullanılan enjeksiyon yöntemleri ultasonografi eşliğinde yapılabildiği gibi, palpasyonla hassas nokta belirlenerek de yapılabilmektedir. Proloterapi uygulaması açısından iki yöntemi karşılaştıran literatür verisine rastlanılmadı. Bu konuda steroid enjeksiyonları ile ilgili yapılan çalışmalar olmakla birlikte, hangi yöntemin daha etkin olduğu konusunda fikir ayrılıkları bulunmaktadır. Tsai ve arkadaşlarınca yapılan çalışmada; PF bulunan hastalarda ultrasonografi eşliğinde veya palpasyon baz alınarak yapılan steroid enjeksiyonunun etkinlikleri karşılaştırılmış; çalışmalarının sonunda ultrasonografi eşliğinde enjeksiyon önerilmiştir (26). Yücel ve arkadaşlarınca yapılan benzer bir çalışmada ise; ultrasonografi eşliğin- de, sintigrafi eşliğinde ve palpasyon baz alınarak yapılan steroid enjeksiyonları karşılaștırılmış; ortalama 25. ay sonunda gruplar arasinda anlamlı fark belirlenememiştir (27).

Buradaki çalışmada enjeksiyonlar palpasyonla hassas nokta belirlendikten sonra plantar fasya başlangıcı hedeflenerek medial ve lateral yaklaşımla uygulandı. Enjeksiyonlar sırasında ultrasonografi kullanılmamış olması çalışmanın eksikliği olarak ifade edilebilir. Ancak tedavi sonrası bulunan olumlu sonuçlara bakılarak kullanılan tekniğin bir dezavantaj oluşturmadığı düşünülmektedir.

Literatür araştırması sonucunda PF tedavisinde proloterapi uygulamasının etkinliğini araştıran yalnızca iki adet çalışmaya rastlandı $(24,25)$. Bu çalışmalarda uygulanan metodlar farklı olmakla birlikte, PF tedavisinde proloterapinin etkin olduğu ifade edilmiştir.

Ryan ve arkadaşları tarafından 2009 yılında yapılan prosektif çalışmada; en az altı aydır yakınması bulunan üçü erkek 17'si kadın toplam 20 PF'li hastaya \%25'lik dekstroz enjeksiyonu yapılmış; enjeksiyonlar altı hafta arayla ortalama üç kez uygulanmış; değerlendirme için VAS (istirahat, günlük aktiviteler ve fiziksel aktivite sonrası) skorlarına bakılmış; ortalama 11.8 ay (6-20 ay) sonra yapılan değerlendirmeler sonucunda VAS skorlarında istatistiksel olarak anlamlı düşüş rapor edilmiştir $(\mathrm{p}<0.0001)$ (24).

Kim ve Lee tarafından yapılmış çift kör randomize kontrollü bir çalışmada; PF tedavisinde trombositten zengin plazma (TZP) ve proloterapi uygulamalarının etkinliği karşılaştırılmıştır. Çalışmaya tek taraflı ve semptomları en az altı aydır bulunan, klinik ve radyolojik olarak tanısı doğrulanmıș hastalar dâhil edilmiștir. Onbir hastaya trombositten zengin plazma (TZP), 10 hastaya ise \%15'lik dekstroz çözeltisi iki hafta arayla toplamda iki kez enjekte edilmiştir. Enjeksiyonlar ultrasonografi eşliğinde peppering tekniği ile beş noktaya uygulanmıștır. Değerlendirme amaçlı ayak fonksiyon indeksi (FFI) kullanılmış. 10 ve 28. hafta sonunda yapilan kontrollerde TZP lehine daha fazla iyileșme görülmekle birlikte, gruplar arasında anlamlı fark olmadığı bil- 
dirilmiştir. Proloterapi grubunda 28. hafta sonunda yapılan değerlendirmede istatistiksel olarak anlamlı iyileșme rapor edilmiştir $(\mathrm{p}=0.011)$ (25). Bu çalışma hasta seçimi, seans sayısı, seans aralığı ve kullanılan dekstroz yoğunluğu bakımından bizim çalışmamızla benzerlik göstermektedir.

Buradaki araştırmada; sonuç değerlendirmesi için birçok çalışmaya benzer şekilde, görsel ağrı ölçeği (VAS) ile ayak-ayak bileği araștırması (FAOS) kullanıldı. Daha önceki çalışmalarda VAS skorunun, sabah ilk adım sonrası, günlük aktiviteler sonrası gibi farklı zamanlardaki değerlerine bakılmıştır. Çalışmamızda; PF bulunan hastalarda tanı koydurucu olarak da değerlendirilen sabah ilk birkaç adım sonrası VAS bakıldı. Farklı araştırmacılar hastalığın günlük aktivitelere ve yaşam kalitesine etkisini değerlendirmek için Roles \& Maudsley, SF-36, AOFAS, FAOS ve FFI gibi çeşitli skorlamalar kullanmışlardır (28-34). $\mathrm{Bu}$ çalışmada mevcut problemin günlük yaşama, iş hayatına, spor aktivitelerine ve yaşam kalitesine etkisini incelemeye olanak sağlayan FAOS skorunun kullanılması tercih edildi. Araștırma neticesinde VAS ve FAOS verilerinde anlamlı iyileşme gözlendi.

Fonksiyonel durumu objektif olarak değerlendirebilmek için ise bilgisayarlı denge cihazından elde edilen genel/overall stabilite indeksi (OSI) sonuçlarına bakıldı. Şimdiye kadar yapılan araştırmalarda PF bulunan hastalarda denge ve koordinasyon testi kullanılmamıştır. Bu açıdan çalışmanın bu parametrenin kullanıldığı ilk araştırma olduğu ifade edilebilir. Araştırmada overall stabilite indeksi (OSI) değerleri açısından tedavi sonrasında anlamlı olarak düzelme gözlendi. Bununla birlikte, PF bulunan ekstremiteler ile sağlam tarafların OSI sonuçları arasındaki fark azalmasına rağmen istatistiksel olarak anlamlılığını korumaktaydı. Buradan hareketle OSI değerlerinin normalleşme eğiliminde olduğu ve bunun da iyileşme göstergesi olabileceği belirtilebilir.

Denge; görsel, işitsel ve sinirsel uyarıların birlikteliği ile ağırlık merkezindeki değişikliklere uyum sağlama yeteneğidir ve kas iskelet sistemi ile sinir sisteminin koordine çalışmasıyla korunur
(35). Dengenin korunmasında propriosepsiyon önemli rol oynamaktadır. Propriosepsiyon; eklem kapsülü, ligament, kas, tendon ve deride bulunan mekanoreseptörlerden alınan nöral uyarlların bütünü olarak ifade edilmektedir (36). Mekanoreseptörler her ne kadar dokunma, basınç ve proprioseptif duyunun iletiminde rol alsa da, son zamanlarda ağrı iletiminde de rol aldığı ifade edilmektedir (37). Bazı ağrılı durumların postüral stabiliteye etkisini araştıran çalışmalar bulunmaktadır. Aydoğ ve ark.nın yaptıkları bir çalışmada romatoid artrit varlığının postüral stabiliteyi olumsuz etkilediği bildirilmiştir (38). Akbari ve ark. tarafından yapılan çalışmada; akut ayak bileği bağ yaralanmalarının propriosepsiyon kaybına neden olarak postüral stabiliteyi olumsuz etkilediği ifade edilmiştir (39).

Plantar fasyanın propriosepsiyona etkisini araştıran çalışma bulunmamakla birlikte; ligamentöz yapısı gereği içerisinde proprioseptif reseptörlerin varlığı dışlanamaz. PF varlığının propriosepsiyonu bozarak dengeyi olumsuz etkileyebileceği düşünülebilir. Ağrının derin duyu akışını engellemesi dengeyi bozmuş olabilir (40). Çalışmamızda OSI değerlerinde oluşan değişimler bu varsayımı desteklemektedir.

Uygulamalar sirasinda hissedilen ve uygulama sonrası 1-2 güne kadar devam edebilen ağrı dışında herhangi bir yan etki görülmedi. Bu yan etki nesnel olarak değerlendirilmemekle birlikte, hastaların tamamı iğne ağrısından şikâyet etmişlerdir. Bu durumun takip oranının düşmesinde önemli bir etken olduğu söylenebilir.

Çalışmada hasta grubuna altı haftalık egzersiz programı verildi. PF tedavisinde egzersiz uygulamasının etkinliği göz önüne alındığında; hastalardaki klinik iyileşmede egzersizin proloterapiden daha önemli paya sahip olduğu düşünülebilir. Bununla birlikte çalışmamızda sadece egzersiz tedavisi alan bir grup bulunmadığ için bunu ifade etmek zordur.

Araştırmanın eksik yönleri olarak; hasta sayısının azlığı, kontrol grubu bulunmaması ve değerlendirmenin üç ay gibi kısa bir sürede yapılmış olması söylenebilir. Her ne kadar seçilen hastalar uzun süredir yakınması olan ve daha önce çeşitli 
konservatif yöntemlerle tedavi edilmeye çalışılmış hastalar olsa da, proloterapi grubuna karşıllk bir kontrol grubu tasarlansaydl, uygulamanın etkinliği olumlu veya olumsuz anlamda daha iyi gösterilebilirdi. Ayrıca üçüncü ayda hastalardan beklenilen tedavi yanıtı alınmış olmasına rağmen, sonraki aylarda hastaların takibi yapılmadığından olası olumsuzluklar tespit edilemedi. Yukarıdaki sebepler proloterapinin etkin bir tedavi yöntemi olduğunu söylemeden önce bazı çekinceler konmasına neden olmaktadir.

Sonuç olarak; çalışmamızın PF tedavisinde proloterapi uygulamasının etkinliğini araștıran az sayıdaki çalışmadan birisi olduğu ifade edilebilir. Proloterapi uygulaması; klinisyenin deneyimi doğrultusunda kolaylıkla uygulanabilen ve konservatif yöntemlerle tedavi edilemeyen PF vakalarında tercih edilebilecek bir yöntem olarak görünmektedir. Bununla birlikte, daha etkin tedavi yöntemlerini belirlemek için iyi tasarımlanmıș çalıșmalara gerek duyulmaktadır. Aynı zamanda proloterapi uygulamasında standart tedavi rehberlerinin oluşturulabilmesi için de geniş kapsamlı çalışmalar gerekmektedir.

\section{KAYNAKLAR}

1. Rompe JD. Plantar fasciopathy. Sports Med Arthrosc. 2009 Jun;17(2):100-4.

2. Neufeld SK, Cerrato R. Plantar fasciitis: evaluation and treatment. J Am Acad Orthop Surg. 2008;16(6):338-46.

3. Wearing SC, Smeathers JE, Urry SR, et al. The pathomechanics of plantar fasciitis. Sports Med. 2006;36(7): 585-611.

4. Goff JD, Crawford R. Diagnosis and treatment of plantar fasciitis. Am Fam Physician. 2011;84(6):676-82.

5. Rosenbaum AJ, DiPreta JA, Misener D. Plantar heel pain. Med Clin North Am. 2014;98(2):339-52.

6. Buchbinder R. Clinical practice. Plantar fasciitis. $N$ Engl J Med. 2004;350(21):2159-66.

7. Toomey EP. Plantar heel pain. Foot Ankle Clin. 2009;14(2):229-45.

8. Acevedo JI, Beskin JL. Complications of plantar fascia rupture associated with corticosteroid injection. Foot Ankle Int. 1998;19(2):91-7.

9. Dyck DD Jr, Boyajian-O'Neill LA. Plantar fasciitis. Clin J Sport Med. 2004;14(5):305-9.

10. DeChellis DM, Cortazzo MH. Regenerative medicine in the field of pain medicine: Prolotherapy, platelet-rich plasma therapy, and stem cell therapy-Theory and evidence. Techniques in Regional Anesthesia and Pain Management. 2011;15(2):74-80.

11. Yildiz Y, Apaydin AH, Seven MM, et al. The effects of prolotherapy (hypertonic dextrose) in recreational athletes with patellofemoral pain syndrome. J Exp Integr Med. 2016;6(2):53-6.

12. Weiss L. Prolotherapy. In: Weiss L, Silver JK, Lennard TA, Weiss JM, Eds. Easy Injections. Philadelphia: ButterworthHeinemann; 2007. p. 166-71.

13. Nair LS. Prolotherapy for tissue repair. Transl Res. 2011;158(3):129-31.

14. Rabago D, Slattengren A, Zgierska A. Prolotherapy in primary care practice. Prim Care. 2010;37(1):65-80.

15. Parraca JA, Olivares PR, Carbonell Baeza A, et al. TestRetest reliability of Biodex Balance SD on physically active old people. J. Hum Sport Exerc. 2011;6(2):444-51.

16. Smith BS, Burton B, Johnson D, et al. Effects of wearing athletic shoes, five - toed shoes, and standing barefoot on balance performance in young adults. Int J Sports Phys Ther. 2015;10(1):69-74.

17. Roos EM, Brandsson S, Karlsson J. Validation of the foot and ankle outcome score for ankle ligament reconstruction. Foot Ankle Int. 2001;22(10):788-94.

18. Karatepe AG, Günaydın R, Kaya T, et al. Validation of the Turkish version of the foot and ankle outcome score. Rheumatol Int. 2009;30(2):169-73.

19. Riddle DL, Schappert SM. Volume of ambulatory care visits and patterns of care for patients diagnosed with plantar fasciitis: a national study of medical doctors. Foot Ankle Int. 2004;25(5):303-10.

20. Riddle DL, Pulisic M, Pidcoe P, et al. Risk factors for plantar fasciitis: a matched case-control study. J Bone Joint Surg Am. 2003 May;85-A(5):872-7.

21. Rano JA, Fallat LM, Savoy-Moore RT. Correlation of heel pain with body mass index and other characteristics of heel pain. J Foot Ankle Surg. 2001;40(6):351-6.

22. Cutts S, Obi N, Pasapula C, et al. Plantar fasciitis. Ann $R$ Coll Surg Engl. 2012;94(8):539-42.

23. Healey K, Chen K. Plantar fasciitis: current diagnostic modalities and treatments. Clin Podiatr Med Surg. 2010; $27(3): 369-80$.

24. Ryan MB, Wong AD, Gillies JH, et al. Sonographically guided intratendinous injections of hyperosmolar dextrose/lidocaine: a pilot study for the treatment of chronic plantar fasciitis. BrJ Sports Med. 2009;43(4):303-6.

25. Kim E, Lee JH. Autologous platelet-rich plasma versus dextrose prolotherapy for the treatment of chronic recalcitrant plantar fasciitis. PM R. 2014;6(2):152-8.

26. Tsai WC, Hsu CC, Chen CP, et al. Plantar fasciitis treated with local steroid injection: comparison between sonographic and palpation guidance. J Clin Ultrasound. 2006;34(1):12-6. 
27. Yucel I, Yazici B, Degirmenci E, et al. Comparison of ultrasound-, palpation-, and scintigraphy-guided steroid injections in the treatment of plantar fasciitis. Arch Orthop Trauma Surg. 2009;129(5):695-701.

28. Gerdesmeyer L, Frey C, Vester J, et al. Radial extracorporeal shock wave therapy is safe and effective in the treatment of chronic recalcitrant plantar fasciitis: results of a confirmatory randomized placebo-controlled multicenter study. Am J Sports Med. 2008;36(11):2100-9.

29. Gollwitzer H, Diehl P, von Korff A, et al. Extracorporeal shock wave therapy for chronic painful heel syndrome: a prospective, double blind, randomized trial assessing the efficacy of a new electromagnetic shock wave device. J Foot Ankle Surg. 2007;46(5):348-57.

30. Ibrahim MI, Donatelli RA, Schmitz C, et al. Chronic plantar fasciitis treated with two sessions of radial extracorporeal shock wave therapy. Foot Ankle Int. 2010;31(5):391-7.

31. Malay DS, Pressman MM, Assili A, et al. Extracorporeal shockwave therapy versus placebo for the treatment of chronic proximal plantar fasciitis: results of a randomized, placebo-controlled, double-blinded, multicenter intervention trial. J Foot Ankle Surg. 2006;45(4):196-210.

32. Marks W, Jackiewicz A, Witkowski Z, et al. Extracorporeal shock-wave therapy (ESWT) with a new-generation pneumatic device in the treatment of heel pain A double blind randomised controlled trial. Acta Orthop Belg. 2008;74(1):98-101.
33. Rompe JD, Decking J, Schoellner C, et al. Shock wave application for chronic plantar fasciitis in running athletes. A prospective, randomized, placebo-controlled trial. Am J Sports Med. 2003;31(2):268-75.

34. Speed CA, Nichols D, Wies J, et al. Extracorporeal shock wave therapy for plantar fasciitis. A double blind randomised controlled trial. J Orthop Res. 2003;21(5): 937-40.

35. Balaban Ö, Nacır B, Erdem H, et al. Denge fonksiyonunun değerlendirilmesi. J Phys Med Rehabil Sci. 2009;12:133-9.

36. Aydin T, Yildiz Y, Yildiz C, et al. Proprioception of the ankle: a comparison between female teenaged gymnasts and controls. Foot Ankle Int. 2002;23(2):123-9.

37. Schleip R. Fascial plasticity-a new neurobiological explanation. J Bodywork Mov Ther. 2003;7:11-9,104-16.

38. Aydoğ E, Bal A, Aydoğ ST, et al. Evaluation of dynamic postural balance using the Biodex Stability System in rheumatoid arthritis patients. Clin Rheumatol. 2006; 25(4):462-7.

39. Akbari M, Karimi H, Farahini H, et al. Balance problems after unilateral lateral ankle sprains. J Rehabil Res Dev. 2006;43(7):819-24.

40. Sekir U, Yildiz Y, Hazneci B, et al. Effect of isokinetic training on strength, functionality and proprioception in athletes with functional ankle instability. Knee Surg Sports Traumatol Arthrosc. 2007;15(5):654-64. 